\title{
Cacat Yuridis dan Cacat Administrasi Dalam Pembatalan Sertifikat Hak Atas Tanah
}

\section{Isis Ikhwansyah ${ }^{1}$}

Fakultas Hukum Universitas Padjadjaran, Jln. Raya Bandung-Sumedang Km. 21. Jatinangor, Kab. Sumedang 45363, Telp. (022) 842 88888, Fax. (022) 84288898

Email: isisikhwansyah@mail.com

\section{Djumardin $^{2}$}

Fakultas Hukum Universitas Mataram, Jln. Majapahit No. 62 Mataram 83125, Telp. (0370), 633035, Fax. 626954

Email:djumardin@unram.ac.id

\section{ABSTRAK}

Penelitian ini dimaksudkan untuk menjawab dua isu hukum utama yaitu : 1). Indikator apakah yang menjadi syarat adanya cacat yuridis dan cacat administrasi dalam proses penerbitan sertifikat hak atas tanah oleh Badan Pertanahan Nasional (BPN)? 2). Bagaimanakah implikasi yuridis legalitas sertifikat kepemilikan hak atas tanah yang mengandung cacad yuridis dan cacad administrasi?

Jenis penelitian yang digunakan yaitu penelitian hukum normatif Dengan menggunakan pedekatan, perundang-undangan, pendekatan konseptual dan pendekatan kasus. Tekhnik pengumpulan bahan hukum dilakukan dengan cara penelitian kepustakaan dan analisis secara kualitatif dengan pola berpikir menggunakan metode kajian induktif.

Berdasarkan hasil penelitian menunjukkan bahwa : 1). Bahwa dengan mengacu pada Ketentuan Pasal 64 ayat (3) Perkaban No. 3 Tahun 2011 dapat disimpulkan bahwa pembatalan hak berdasarkan putusan pengadilan umum baik perdata maupun pidana dikategorikan sebagai pembatalan hak karena cacat administrasi dan hanya Putusan Peradilan Tata Usaha Negara yang dikategorikan sebagai cacat hukum karena hanya Putusan PTUN yang secara tegas memerintahkan pembatalan sertipikat hak atas. 2). Adanya Keputusan PTUN tidak secara otomatis merubah legalitas kepemilikan Hak atas tanah seseorang, melainkan dengan keputusan PTUN tersebut oleh para pihak dapat dijadikan alat bukti ketika mengajukan gugatan kepemilikan hak atas tanah ke Pengadilan Negeri. Sedangkan terhadap Putusan Pengadilan Negeri yang terkait dengan adanya cacad yuridis dalam proses penerbitan sertifikat dapat

1 Dosen Fakultas Hukum Universitas Padjadjaran.

2 Dosen Fakultas Hukum Universitas Mataram. 
menjadi dasar bagi pemilik hak atas tanah untuk menindaklanjuti ke BPN untuk proses penerbitan sertifikat berdasarkan Putusan Pengadilan yang telah berkekuatan hukum tetap.

Kata Kunci : Cacat yuridis dan cacat administrasi, Pembatalan.

\section{A. PENDAHULUAN}

Tanah merupakan salah satu sumber daya alam yang sangat dibutuhkan oleh manusia untuk mencukupi kebutuhan hidupnya baik langsung untuk kehidupannya seperti misalnya untuk bercocok tanam guna mencukupi kebutuhannya (tempat tinggal, perumahan), maupun untuk melaksanakan usahanya seperti untuk tempat perdagangan, industri, pendidikan, pembangunan sarana dan prasarana lainnya.

Dalam memori penjelasan II/8 UUPA, menyebutkan bahwa tanah untuk persediaan, peruntukkan, dan penggunaannya harus melalui perencanaan". ${ }^{1}$

Secara filsafati, bahwa konsepsi hukum agraria nasional yang menghendaki adanya perencanaan umum mengenai pemanfaatan bumi, air, dan ruang angkasa serta kekayaan alam yang terkandung di dalamnya yang sesuai dengan daya dukung dan kemampuannya untuk keperluan negara, agama, masyarakat sosial budaya, perkembangan pertanian, perikanan, industri, transportasi, transmigrasi dan pertambangan.

Peran penting dari tanah dapat dilihat dalam pengaturan Konstitusi Negara Republik Indonesia pada Pasal 33 Undang Undang Dasar tahun 1945 yang menegaskan bahwa bumi, air dan kekayaan alam yang terkandung di dalamnya dipergunakan untuk sebesar-besar kemakmuran rakyat. Salah satu upaya yang dilaksanakan untuk dapat mewujudkan tujuan sebesar-besarnya kemakmuran rakyat ini adalah dengan membentuk Undang-undang No. 5 Tahun 1960 tentang Peraturan Dasar Pokok-pokok Agraria (Undang-undang Pokok Agraria, selanjutnya disingkat UUPA).

Selanjutnya adalah tindak lanjut dari penanganan masalah pertanahan ini yang perlu mendapat perhatian adalah masuk kedalam ranah hukum yang mana, perdata (adat), pidana atau sengketa Tata Usaha Negara. Model penanganan penyelesaian apakah diselesaikan diluar (out court of resettlement ) melalui musyawarah atau mediasi atau masuk keranah lembaga peradilan ( in court of resettlement) maka kita bicara kompetensi atau kewenangan lembaga hukum peradilan mana, Peradilan umum atau Peradilan Tata Usaha Negara.

Lembaga peradilan sebagai ujung tombak harapan terakhir dalam rangka penyelesaian sengketa pertanahan kadang dirasakan oleh pihak tertentu yang bersengketa menjadi tidak mencerminkan keadilan hukum yang dicari. Dengan kata lain hukum tidak selalu dapat menyelesaikan persoalan sengketa pertanahan secara tuntas, tetap ada aspek lain yang harus dipertimbangkan.

Dalam rangka penyelesaian sengketa pertanahan sebagai ujung tombak terakhir dilakukan oleh pihak tertentu adalah melakukan gugatan ke ranah hukum perdata, ranah hukum pidana yang diperiksa, diadili dan diputus melalui Peradilan Umum atau sengketa Tata Usaha Negara diperiksa, diadili dan diputus melalui Peradilan Tata Usaha Negara (PERATUN ).

Hal tersebut diatas adalah disebabkan dualisme kedudukan sertifikat

1. A.P. Parlindungan, Komentar Atas Undang-Undang Pokok Agraria, (Bandung, Alumni, 1988), hlm. 50. 
hak atas tanah yang bersumber dari 2 (dua) aspek hukum, yaitu:

1. Sertifikat hak atas tanah sebagai Keputusan Tata Usaha Negara (KTUN ), menurut Pasal 1 Angka (3) Undang Undang Nomor 5 Tahun 1986 tentang Peratun dan;

2. Sertifikat hak atas tanah sebagai tanda bukti hak menurut Pasal 31 dan 32 Peraturan Pemerintah Nomor 24 Tahun 1997 tentang Pendaftaran Tanah. Dengan kata lain, sertifikat tersebut mengandung data fisik dan yuridis yang erat hubungannya dengan hak keperdataan seseorang.

Ketentuan dalam Peraturan Kepala Badan Pertanahan Nasional (Perkaban) No. 3 Tahun 2011 tentang Pengelolaan Pengkajian dan Penanganan Kasus Pertanahan tidak secara khusus mengatur mengenai pembatalan hak atas tanah namun diatur dalam ketentuan mengenai penyelesaian kasus pertanahan pada $\mathrm{Bab}$ VII dengan memberikan pengaturan bahwa penyelesaian kasus pertanahan pada dasarnya ada 2 (dua) yaitu 1) pelaksanaan putusan pengadilan dan 2) penyelesaian kasus pertanahan di luar pengadilan. Pelaksanaan putusan pengadilan serta penyelesaian kasus pertanahan di luar pengadilan dapat melahirkan perbuatan hukum berupa pembatalan sertipikat hak atas tanah sehingga dapat dikatakan bahwa jika didasarkan pada Peraturan Kepala Badan Pertanahan Nasional (Perkaban) No. 3 Tahun 2011 maka pembatalan hak atas tanah dapat dilakukan dengan 2 (cara) yakni 1) berdasarkan putusan pengadilan dan 2) tidak berdasarkan putusan pengadilan.

Pada dasarnya ketentuan Peraturan Kepala Badan Pertanahan Nasional (Perkaban) No. 3 Tahun 2011 memberikan pengaturan bahwa Pembatalan Sertipikat Hak atas Tanah yang didasarkan pada
Putusan Pengadilan namun Putusan Pengadilan yang tidak secara tegas menyatakan batal sertipikat tetapi memiliki amar yang bermakna menimbulkan akibat hukum terbitnya, beralihnya atau batalnya hak dikategorikan sebagai pembatalan sertipikat hak atas tanah karena cacat admnistrasi.

Dengan demikian terkait dengan pembatalan sertifikat secara normatif menunjukkan adanya kekaburan norma, khususnya jika dikaitkan dengan kewenangan dan konsekwensi yuridis dari adanya pembatalan oleh Lembaga Peradilan. Atas dasar itulah maka menjadi relevan untuk dikaji tentang :

1). Indikator apakah yang menjadi syarat adanya cacat yuridis dan cacat administrasi dalam proses penerbitan sertifikat hak atas tanah oleh Badan Pertanahan Nasional (BPN)?

2). Bagaimanakah implikasi yuridis legalitas sertifikat kepemilikan hak atas tanah yang mengandung cacad yuridis dan cacad administrasi?

\section{B. PEMBAHASAN}

\section{a. Indicator cacad yuridis dan cacad administrasi dalam penerbitan sertifikat Hak Atas Tanah}

Tujuan dibentuknya Peradilan Tata Usaha Negara atau Peradilan Adiministrasi Negara, adalah dimaksudkan sebagai suatu sarana perlindungan hukum (rechtsbescherming) bagi rakyat terhadap tindakan Pemerintah agar dalam menjalankan tugas pemerintahan sesuai dengan peraturan perundang-undangan yang berlaku (wetmatigheid van bestuur) dan selaras dengan asas-asas umum pemerintahan yang baik (AUPB)/ algemene beginselen van behoorlijk bestuur.

Dilihat dari aspek historis, tujuan pembentukan Peradilan Tata Usaha Negara 
menurut Keterangan Pemerintah Di

Hadapan Sidang Paripurna Dewan

Perwakilan Rakyat Republik Indonesia

Mengenai Rancangan Undang-Undang Tentang Peradi|an Tata Usaha Negara, pada tanggal 29 April 1906 yang disampaikan oleh Menteri Kehakiman Ismail Saleh, adalah, Peradilan Tata Usaha Negara itu diadakan dalam rangka memberi perlindungan kepada rakyat, ${ }^{2}$ tujuan ini dicantumkan dan dipertegas kembali di dalam Penjelasan Umum Undang-Undang Nomor 5 Tahun 1986 Tentang Peradilan Tata Usaha Negara pada bagian angka 1 (satu) alinea 8 (delapan) menjelaskan sebagai berikut :

Peradilan Tata Usaha Negara itu diadakan dalam rangka memberikan perlindungan kepada rakyat pencari keadilan, yang merasa dirinya dirugikan akibat suatu Keputusan Tata Usaha Negara. Akan tetapi, dalam hubungan ini perlu kiranya disadari bahwa disamping hak perseorangan, masyarakat juga mempunyai hak hak-hak tertentu. Hak Masyarakat ini didasarkan kepentingan bersama dari orang yang hidup dalam masyarakat tersebut. Kepentingankepentingan tersebut tidak selalu sejalan, bahkan kadang-kadang saling berbenturan. Untuk menjamin penyelesaian yang seadil-adilnya terhadap benturan antara kepentingan yang berbeda itu, saluran hukum merupakan salah satu jalan yang terbaik dan sesuai dengan prinsip yang terkandung dalam falsafah negara kita Pancasila, maka hak dan kewajiban asasi warga masyarakat harus diletakkan dalam keserasian, keseimbangan, dan keselarasan antara kepentingan masyarakat. Oleh karena itu, tujuan Peradilan Tata Usaha Negara sebenarnya tidak semata-mata memberikan perlindungan terhadap hak-hak perorangan, tetapi sekaligus juga

\section{melindungi hak-hak masyarakat. ${ }^{3}$} (kursif dari penulis)

Dapat ditarik suatu kesimpulan dilihat dari aspek filosofis, historis dan yuridis, bahwa tujuan diadakannya Peradilan Tata Usahai Negara adalah dalam rangka :

1. Memberikan perlindungan terhadap hakhak perseorangan; dan

2. Memberikan perlindungan terhadap hakhak masyarakat.

$\begin{array}{lr}\text { Pencerminan dan } & \text { kongkretisasi } \\ \text { terhadap perlindungan } & \text { hak-hak }\end{array}$ perseorangan dan hak-hak masyarakat antara lain dapat dilihat dan dibaca di dalam Undang-Undang Nomor 5 Tahun 1986 tentang Peradilan Tata Usaha Negara sebagai berikut :

Tabel 1

Pengaturan hak-hak perseorangan dan hak-hak masyarakat dalam UndangUndang Peratun

\begin{tabular}{|l|l|}
\hline $\begin{array}{c}\text { Hak-hak } \\
\text { Perseorangan }\end{array}$ & \multicolumn{1}{|c|}{$\begin{array}{c}\text { Hak-hak } \\
\text { Masyarakat }\end{array}$} \\
\hline Pasal 3, Pasal 51A \\
ayat (2), Pasal 53 \\
ayat (1), Pasal 54 \\
ayat (4), Pasal 60, & Pasal 51A huruf b, d, \\
61, Pasal 63, Pasal 49, \\
67 ayat (2), (3), \\
dan ayat (4) huruf \\
ayat (1) \\
a, Pasal 83, Pasal 67 \\
85, Pasal 93, Pasal \\
98, dan Pasal 116, \\
Pasal 144C, Pasal \\
144D
\end{tabular}

${ }^{3}$ Undang-Undang Nomor 5 Tahun 1986 Tentang Peradilan Tata Usaha Negara, Penjelasan Umum angka 1 alinea 
Dalam konsep Filsafat logika, jika terjadi hubungan yang sejalan dan selaras antara kepentingan hak-hak perseorangan, hak-hak masyarakat dengan kepentingan Pemerintah sebagai penguasa, dikatakan mempunyai nilai yang sama dengan yang lain (ekwipollensi), akan tetapi jika kepentingan yang satu dengan yang lain saling berbenturan, maka terjadi hubungan yang bersifat oposisi (kontraris), hubungan yang bersifat oposisi melahirkan benturan kepentingan.

Terjadinya benturan kepentingan antara hak-hak perseorangan, hak-hak masyarakat dan Pemerintah sebagai penguasa, dalam pandangan filsafat Hukum dimungkinkan terjadi, oleh karena hukum itu berasal dari kesadaran manusia, dalam kesadaran manusia itu sendiri ada tiga tendenz atau kecenderungan :

1. Tendenz individualis;

2. Tendenz kollektivis:

3. Tendenz tata (orde). ${ }^{4}$

Pemberian perlindungan kepada rakyat merupakan amanat dari Pembukaan (Preambule) Undang-Undang Dasar Negara Republik Indonesia Tahun 1945 alInea ke 4 (empat) yang menyebutkan, ... untuk membentuk suatu Pemerintahan Negara Indonesia yang melindungi segenap bangsa Indonesia... ${ }^{5}$ (kursif dari penulis) Perlindungan terhadap segenap bangsa indonesia tidak hanya dari ancaman pihak luar yang bersifat eksternal, akan tetapi termasuk pula dari tindakan Badan atau Pejabat Tata Usaha Negara yang melanggar hukum yang berimplikasi menimbulkan kerugian bagi rakyat.

Di dalam batang tubuh UndangUndang Dasar Negara Republik Indonesia
Tahun 1945 setelah perubahan (amandemen), setidak-tidaknya ada 2 (dua) pasal yang menyebutkan konsep perlindungan yaitu :

\section{Pasal 28D}

Setiap orang berhak atas pengakuan, jaminan, perlindungan, dan kepastian hukum yang adil serta perlakuan yang sama di hadapan hukum.

\section{Pasal 28G}

Setiap orang berhak atas perlindungan diri pribadi, keluarga, kehormatan, martabat, dan harta benda yang dibawah kekuasaannya, serta berhak atas rasa aman dan perlindungan dari ancaman dan perlindungan dari ancaman ketakutan untuk berbuat atau tidak berbuat sesuatu yang merupakan hak asasi.

Berdasarkan ketentuan Pasal 28D ayat (1) dan Pasal 28G ayat (1) tersebut di atas dapat disimpulkan Negara memberikan perlindungan yang luas sekali kepada rakyatnya baik dibidang hukum maupun yang berkaitan dengan internal pribadi, maupun yang bersifat eksternal yaitu keluarga, harta benda dan rasa aman dari segala macam gangguan yang bersifat horisontal maupun vertikal.

Salah satu norma hukum publik yang bersifat individual-kongkrit yang sering dipergunakan oleh Pemerintah dalam melaksanakan tugasnya adalah berupa Keputusan Tata Usaha Negara, dalam rangka norma hukum, Keputusan Tata Usaha Negara merupakan norma penutup. ${ }^{6}$ Ketetapan atau beschikking digolongkan sebagai hukum positif tertulis yang berlaku khusus yang ditetapkan administrasi

\footnotetext{
${ }^{4}$ O Noto Hamidjojo, Soal-Soal Pokok Fisafat Hukum, Griya Media, Salatiga, 2011, hal. 5-6.

${ }^{5}$ Pembukaan (Preambule) Undang-Undang Dasar Negara RI, alinea ke 4 (empat)
}

${ }^{6}$ Philipus M. Hadjon et. al. Pengantar Hukum Administrasi Indonesia (Introduction to the Indonesian Administrative Law), Gajah Mada University Press, Yogyakarta, cet. III, hal. 125 . 
negara. $^{7}$ S. Prajudi Atmosudirjo berpendapat, yang paling banyak menimbulkan permasalahan, dan keresahan yang merupakan masalah besar dikalangan masyarakat antara lain, masyarakat makin lama sangat tergantung dari keputusan para pejabat Administrasi Negara, oleh karena makin lama makin banyak urusan yang diikat kepada suatu izin atau persetujuan pemerintah, ${ }^{8}$ yang dikalangan rakyat terkenal dengan sebutan "keputusan pemerintah". 9 Menurut penulis pandangan S. Prajudi Atmosudirjo melihat keputusan pemerintah dari aspek negatif, sedangkan pendapat yang sebaliknya yang bersifat positif dikemukakan oleh Rusli K. Iskandar, pemerintah guna mengatasi perkembangan yang terjadi, seringkali dalam menjalankan tugas servis publik melakukan penciptaan hukum, terutama untuk menyelesaikan halhal yang belum ada pengaturan hukumnya...Penciptaan hukum yang dimaksud salah satunya tertuang dalam beschikking. ${ }^{10}$ (kursif dari penulis), Benny M. Junus mencoba melihat dari aspek negatif dan positif dengan mengatakan :

\section{Aktifitas-aktifitas Administrasi} Negara dalam rangka melaksanakan, menjalankan dan meyelenggarakan tugas Pemerintah tersebut, sangat beraneka ragam. Salah satu macam kegiatan yang sangat mempengaruhi kehidupan negara dan masyarakat adalah keputusan-keputusan Pejabat Pemerintah yang bersifat yuridis, dan mengandung penetapan (beschikking) yang mempunyai akibat hukum, yang akan membahayakan bila diambil secara kurang bertanggung jawab. ${ }^{11}$

Di Indonesia Keputusan Tata-Usaha Negara merupakan istilah tehnis yuridis

\footnotetext{
${ }^{7}$ Bagir Manan, Hukum Positif Indonesia (Suatu Kajian Teoritik), FH UII Press, Yogyakarta, 2004, cet. pertama, hal. 16-17.

${ }^{8}$ S. Prajudi Atmosudirdjo, Hukum Administrasi Negara, Ghalia Indonesia, Jakarta, 1981, cetakan keempat, hal. 79.

${ }^{9}$ Ibid, hal. 83 .
}

yang pengertiannya sudah dibakukan, diberi bentuk, dan isi di dalam UndangUndang Nomor 51 Tahun 2009 tentang Perubahan Kedua Atas Undang-Undang Nomor 5 Tahun 1986 tentang Peradilan Tata Usaha Negara di dalam Pasal 1 angka 9, dalam tataran doktrin menurut pandangan beberapa sarjana untuk istilah Keputusan Tata Usaha Negara, seperti E. Utrecht menggunakan istilah penetapan, Prajudi Atmosudirdjo menggunakan istilah yang sama dengan E. Utrecht yaitu penetapan, sedangkan Kuntjoro Purbopranoto memakai istilah keputusan. Istilah-istilah tersebut mempunyai sifat yang khas yaitu konkrit, kasuistis, dan Individual.

Konsep Keputusan Tata Usaha Negara (beschikking) menurut UndangUndang Nomor 5 Tahun 1986 tentang Peradilan Tata Usaha Negara sebagaimana telah diubah beberapa kali dan terakhir dengan Undang-Undang Nomor 51 Tahun 2009 tentang Perubahan Kedua Atas Undang-Undang Nomor 5 Tahun 1986 tentang Peradilan Tata Usaha Negara, tidak saja dalam pengertian tindakan secara aktif mengeluarkan atau menerbitkan Keputusan Tata Usaha Negara, akan tetapi diperluas (expantion) termasuk di dalamnya tindakan Badan atau Pejabat Tata Usaha Negara yang bersifat pasif atau sikap diam atau dalam praktek dikenal dengan istilah keputusan fiktif negatif, dianggap (fiksi) menolak untuk mengeluarkan Keputusan Tata Usaha Negara.

Selain adanya perluasan (expantion) konsep Keputusan Tata Usaha Negara, dilakukan juga pembatasan (restriction) terhadap konsep Keputusan Tata Usaha Negara meskipun hal tersebut telah memenuhi unsur sebagai suatu Keputusan Tata Usaha Negara dalam ilmu perundangundangan disebut dengan tekhnik

\footnotetext{
${ }^{10}$ Rusli K. Iskandar, Normatifisasi Hukum Administrasi Negara, dalam SF Marbun et. al (Penyunting) Dimensi-Dimensi Pemikiran Hukum Administrasi Negara, UII Press, Yogyakarta, 2001, hal. 176.

${ }^{11}$ Benny M. Junus, Intisari Hukum Administrasi Negara, Alumni, Bandung, 1980, hal. 29.
} 
pengecualian. Pembatasan (restriction) dapat dibedakan menjadi pembatasan langsung (direct restriction) dan pembatasan tidak langsung (indirect restriction).

Ketika suatu Keputusan Tata Usaha Negara dikeluarkan/diterbitkan atau dipublikasikan/diumumkan, maka mempunyai kekuasaan hukum (rechtskracht), menurut Stellinga suatu perbuatan pemerintah mempunyai kekuasaan hukum (rechtskracht), bilamana dapat mempengaruhi pergaulan hukum. ${ }^{12}$ Dengan kata lain Keputusan Tata Usaha Negara (beschikking) mempunyai daya laku (gelding) dan daya ikat (gebonden) terhadap pihak yang dituju (adressat).

Berdasarkan asas praduga sah (praesumtio iustae causa/vermoeden van rechtmatigheid) Keputusan Tata Usaha Negara selalu dianggap sah dan harus dilaksanakan sepanjang belum dibatalkan berdasarkan putusan pengadilan yang telah memperoleh kekuatan hukum tetap, dengan demikian adanya gugatan tidak menunda dilaksanakannya Keputusan Tata Usaha Negara, asas ini di normatatifisasi/normering di dalam Pasal 67 ayat (1) Undang-Undang Nomor 5 Tahun 1986 tentang Peradilan Tata Usaha Negara.

Jika terjadi tindakan pemerintah di dalam mengeluarkan Keputusan Tata Usaha Negara (beschikking) dalam rangka pengaturan, pengawasan, maupun dalam rangka penegakan hukum adminsitrasi menimbulkan benturan kepentingan dengan rakyat, dalam hal ini orang perorangan (persoon) atau badan hukum (recht

\footnotetext{
${ }^{12}$ Stellinga, dalam E. Utrecht, Pengantar Hukum Admnistrasi Negara Indonesia, Pustaka Tinta Mas, Surabaya, 1986, hal. 163

${ }^{13}$ Philipus M. Hadjon, Perlindungan hukum bagi Rakyat Indonesia, pt. Bina ilmu, Surabaya, 1987, hal. 1.

${ }^{14}$ Philipus M. Hadjon, Fungsi Normatif Hukum Administrasi Dalam Mewujudkan Pemerintahan Yang Bersih (Pidato pada peresmian penerimaan jabatan Guru Besar dalam
}

persoon), dan benturan kepentingantersebut diajukan sebagai suatu Sengketa Tata Usaha Negara di Pengadilan Tata Usaha Negara, maka atas dasar permohonan dari Penggugat yang dicantumkan dalam gugatan atau diajukan secara terpisah, Pengadilan Tata Usaha Negara dapat menunda pelaksanaan dari Keputusan Tata Usaha Negara.

Perlindungan hukum di dalam Hukum Administrasi Belanda dikenal dengan istilah "rechtsberscherming van de burgers tegen de overheid". ${ }^{13}$ Perlindungan hukum bagi rakyat merupakan salah satu konsep dasar hukum administrasi, unsur-unsur utama hukum administrasi adalah hukum mengenai kekuasaan memerintah yang sekaligus dikaitkan dengan hukum mengenai peranserta masyarakat dalam pelaksanaan pemerintahan, hukum mengenai organisasi pemerintah dan hukum mengenai perlindungan hukum bagi rakyat. ${ }^{14}$ menurut Sulistyandari, perlindungan hukum itu berkaitan bagaimana hukum memberikan keadilan yaitu memberikan atau mengatur hak dan kewajiban terhadap subyek hukum, selain itu juga berkaitan bagaimana hukum memberikan keadilan terhadap subyek hukum yang dilanggar haknya untuk mempertahankan haknya tersebut. ${ }^{15}$

Dilihat dari aspek Ilmu Logika kata keadilan merupakan konsep yang abstrak, oleh karenanya diperlukan suatu isi dari keadilan itu sendiri dengan memberi ciriciri atau pembatasan dalam bantuk definisi, Plato mendefinisikan keadilan berarti, bahwa setiap golongan berbuat apa yang sesuai dengan tempatnya. ${ }^{16}$ Prinsip

\footnotetext{
Ilmu Hukum pada Fakultas Hukum Universitas Airlangga pada hari Senin tanggal 10 Oktober 1994)

${ }^{15}$ Sulistyandari, Perlindungan Hukum Terhadap

Nasabah Penyimpan Melalui Pengawasan Perbankan Di Indonesia, Program Doktor Ilmu Hukum Pascasarjana Unair, 2011, hal. 56.

${ }^{16}$ Theo Hujbers, Filsafat Hukum Dalam Lintasan sejarah, Kanisius, Yogyakarta, 1982, hal. 23.
} 
keadilan menurut H. L. A. Hart, pelakukan hal-hal yang serupa dengan cara yang serupa, dan perlakukan hal-hal yang berbeda dengan cara yang berbeda. ${ }^{17}$ Definisi yang dikemukakan oleh Plato maupun H.L.A. Hart, menurut penulis pandangan tersebut diilhami oleh prinsip "unicuique suum tribuere".

Dalam konteks lembaga peradilan termasuk Peradilan Tata Usaha Negara sebagai salah satu pelaksana kekuasaan kehakiman untuk menyelenggarakan peradilan, haruslah dalam konteks untuk "menegakkan hukum dan keadilan" sesuai dengan amanat konstitusi Undang-Undang Dasar Negara RI tahun 1945 Pasal 24 ayat (1), atas dasar tersebut Undang-Undang Nomor 48 Tahun 2009 tentang Kekuasaan kehakiman di dalam Pasal 2 ayat (1) menentukan, Peradilan dilakukan "Demi Kedailan berdasarkan Ketuhanan Yang Maha Esa". ${ }^{18}$ Oleh karena itu setiap putusan dan Penetapan lembaga peradilan selalu dimulai dengan irah-irah "Demi Kedailan Berdasarkan Ketuhanan Yang Maha Esa". Kekuatan eksekutorial Putusan dan Penetapan lembaga peradilan ada pada irahirah tersebut.

Peradilan Tata Usaha Negara adalah tempat untuk mempertahakan hak rakyat di bidang hukum publik dan tempat menguji secara hukum (toetsingrehts) terhadap tindakan pemerintah (overheidsopstredent) apakah telah sesuai menurut peraturan perundang-undangan yang berlaku (wetmatigheid) atau sudah sesuai dengan asas-asas umum pemerintahan yang baik (algemene beginselen van behoorlijk bestuur). Pengadilan Tata Usaha Negara dapat disebut (sinonim) dengan Peradilan Administrasi Negara sebagaimana yang dimaksud di dalam Pasal 144 UndangUndang Nomor 5 Tahun 1986 tentang Peradilan Tata Usaha Negara, Diundangkan Pada Tanggal 20 Desember 1986

\footnotetext{
${ }^{17}$ H.L.A. Hart, Konsep Hukum ( The Concept Of Law), terjemahan M. Khoizin, Nusa Media, Bandung, 2009, hal. 256.

${ }^{18}$ Undang-Undang Nomor 48 Tahun 2009 tentang Kekuasaan Kehakiman, Pasal 2 ayat (1).
}

Lembaran Negara Republik Indonesia (LN RI) Tahun 1986 Nomor 77, Tambahan Lembaran Negara Republik Indonesia (TLN RI) Nomor 3344. Penerapannya secara efektif mulai tanggal 14 Januari 1991 berdasarkan Peraturan Pemerintah Nomor 43 Tahun 1991 Lembaran Negara Republik Indonesia Tahun 1991 Nomor 8, kini sudah memasuki usia 21 (dua puluh satu) tahun dwi dasawarsa 14 Januari 1991 - 2012.

Dampak dari luasnya tugas pemerintah dan sifat aktifnya kekuasaan pemerintah di dalam melakukan pengaturan, pengawasan, dan penegakan hukum administrasi memungkinkan timbulnya berbagai jenis Sengketa Tata Usaha Negara, hal ini dikatakan pula oleh Donal A. Rumokoy, dalam negara kesejahteraan sekarang ini tugas pemerintah dalam menyelenggarakan kepentingan umum menjadi sangat luas, kemungkinan melanggar kepentingan rakyat oleh perangkat negara sangat besar. ${ }^{19}$

Benturan kepentingan antara rakyat dengan Badan atau Pejabat Tata Usaha Negara dapat dibaca dan dilihat dari laporan masyarakat kepada Komisi Ombudsman Republik Indonesia terkait dengan dugaan perbuatan Maladministrasi, yaitu perilaku atau perbuatan melawan hukum, melampaui wewenang, menggunakan wewenang untuk tujuan lain dari yang yang menjadi tujuan wewenang tersebut, termasuk kelalaian atau pengabaian kewajiban hukum dalam penyelenggaran pelayanan publik yang dilakukan oleh Penyelenggara Negara dan pemerintahan yang menimbulkan kerugian materiil dan/atau inmateriil bagi masyarakat dan orang perseorangan.

Menurut Sudikno Mertokusumo dalam proses penyelesaian perkara, putusan hakim bukanlah satu-satunya bentuk untuk menyelesaikan perkara. Disamping putusan

\footnotetext{
${ }^{19}$ Donal A. Rumokoy, dalam SF. Marbun, et. al. (editor) Dimensi-Dimensi Pemikiran Hukum Administrasi Negara, UII Press, Yogyakarta
} 
hakim masih ada penetapan hakim. ${ }^{20}$ Demikian pula halnya di Pengadilan Tata Usaha Negara dalam rangka proses penyelesaian sengketa bentuk instrumen hukum penetapan dan putusan dikenal dan mendapat tempat serta memperoleh justfikasi (pembenaran).

Perbedaan antara putusan dan penetapan adalah, putusan merupakan produk dari eigenlijke rechtspraak of contenteuze jurisdictie (peradilan yang sesungguhnya atau kekuasaan mengadili persengketaan, pemecahan sengketa oleh hakim), sedangkan penetapan merupakan produk dari oneigenlijke rechtspraak of voluntaire (peradilan sukarela). ${ }^{21}$ Dalam peradilan sesungguhnya (contenteuze) terdapat dua pihak yang saling bersengketa yaitu Penggugat dan Tergugat, sedangkan dalam peradilan sukarela atau tidak sesungguhnya (voluntaire) yang ada hanya pihak Pemohon saja. Sifat amar/diktum putusan di dalam peradilan sesungguhnya (contenteuze) adalah bisa deklaratoir, constitutif dan condemnatoir, sedangkan dalam peradilan sukarela atau tidak sesungguhnya (voluntaire) adalah bersifat deklaratoir. Pembedaan "Peradilan sesungguhnya" dan "tidak sesunggguhnya" disebabkan karena perbuatan hakim dalam peradilan yang tidak sesungguhnya lebih merupakan perbuatan administratif, sehingga putusannya merupakan suatu penetapan (Pasal 236 HIR, 272 Rbg). ${ }^{22}$ Pandangan Sudikno Mertokusumo tersebut terkait dengan Hukum Acara Perdata yang karakternya berbeda dengan Hukuk Acara Peradilan Tata Usaha Negara.

Pembatalan suatu Keputusan Tata Usaha Negara dapat dilakukan oleh Badan atau Pejabat yang mengeluarkan (spontane vernietiging), Instansi atasan dari Badan atau Pejabat yang mengeluarkan atau karena Putusan Pengadilan. Dalam konsep hukum Administrasi harus pula dibedakan antara perubahan, pencabutan dan pembatalan Keputusan Tata Usaha Negara.

\section{b. Implikasi Yuridis legfalitas Sertifikat hak atas tanah yang mengandung cacad yuridis dan cacad administrasi}

Tujuan pengaturan pertanahan dalam UUPA adalah dalam rangka memberikan jaminan kepastian hukum bagi pemilik tanah dan untuk memberikan jaminan kepastian hukum maka dilaksanakan suatu mekanisme pendaftaran tanah di seluruh Indonesia. Pasal 3 Peraturan Pemerintah No. 24 Tahun 1997 tentang Pendaftaran Tanah.

Pasal 1 Peraturan Pemerintah No. 24 Tahun 1997 tentang Pendaftaran Tanah, memberikan rumusan mengenai pengertian pendaftaran tanah. Pendaftaran tanah adalah rangkaian kegiatan yang dilakukan oleh Pemerintah secara terus menerus, berkesinambungan dan teratur, meliputi pengumpulan, pengolahan, pembukuan dan penyajian serta pemeliharaan data fisik dan data yuridis, dalam bentuk peta dan daftar, mengenai bidang-bidang tanah dan satuansatuan rumah susun, termasuk pemberian sertipikat sebagai surat tanda bukti haknya bagi bidang-bidang tanah. Tujuan pendaftaran tanah dalam PP No. 24 Tahun 1997 adalah memberikan kepastian hukum dan perlindungan hukum, menyediakan informasi kepada pihak-pihak yang berkepentingan dan terselenggaranya tertib administrasi pertanahan. Pasal 4 PP No. 24 Tahun 1997 selanjutnya menegaskan bahwa "untuk memberikan kepastian dan perlindungan hukum sebagaimana

\footnotetext{
${ }^{21}$ N.E. Algra, et. al. Kamus Istilah Hukum Fockema Andreae Belanda-Indonesia, Binacipta, 1983, cet. pertama. Hal. 116.

${ }^{22}$ Sudikno Mertokusumo, op, cit. hal. 4.
} 
dimaksud dalam Pasal 3 huruf a kepada pemegang hak yang bersangkutan diberikan sertipikat hak atas tanah". Jadi dapat dikatakan bahwa upaya untuk mewujudkan kepastian terhadap hak-hak atas tanah dilaksanakan antara lain dengan penerbitan suatu dokumen yang mempunyai kekuatan hukum yang sempurna yakni sertipikat hak atas tanah.

Definisi formal sertipikat dapat dilihat dari Pasal 19 ayat (2) UUPA menegaskan bahwa sertipikat adalah surat tanda bukti hak atas tanah yang berlaku sebagai alat pembuktian yang kuat. Sertipikat sebagai surat bukti tanda hak, diterbitkan untuk kepentingan pemegang hak yang bersangkutan, sesuai dengan data fisik yang ada dalam surat ukur dan data yuridis yang telah di daftar dalam buku tanah. Peraturan Pemerintah Nomor 24 Tahun 1997 merumuskan bahwa sertipikat adalah satu lembar dokumen sebagai surat tanda bukti hak yang memuat data fisik dan data yuridis objek yang di daftar untuk hak atas tanah, hak pengelolaan, tanah wakaf, hak milik atas satuan rumah susun dan hak tanggungan yang masing-masing di bukukan dalam buku tanah.

Keberadaan sertipikat hak atas tanah sebagai surat tanda bukti hak memiliki kekuatan sempurna. Hal ini berarti bahwa selama tidak dapat dibuktikan sebaliknya data fisik dan data yuridis yang tercantum di dalamnya harus diterima sebagai data yang benar. Parlindungan mengemukakan bahwa pasal 19 UUPA menyatakan bahwa sertifikat adalah sebagai alat pembuktian yang kuat, sehingga setiap orang dapat mempermasalahkan tentang kebenaran sertifikat tanahnya, dan jika dapat dibuktikan ketidakbenaran dari hak atas tanah tersebut, maka sertifikat dapat dibatalkan oleh Pengadilan dan Kepala BPN dapat memerintahkan hal tersebut. (Parlindungan, 1999).

Defenisi pembatalan hak atas tanah yang diatur dalam Peraturan Menteri Negara Agraria/Keputusan Kepala Badan Pertanahan Nasional No. 9 Tahun 1999 tentang Pemberian dan Pembatalan Hak Milik atas Tanah Negara masih dapat digunakan mengingat aturan peralihan dalam Peraturan Kepala Badan Pertanahan Nasional (Perkaban) No. 3 Tahun 2011 tentang Pengelolaan Pengkajian dan Penanganan Kasus Pertanahan yakni dalam Pasal 84 menegaskan bahwa Ketentuan Peraturan Menteri Negara Agraria/Kepala Badan Pertanahan Nasional Nomor 9 Tahun 1999 tentang Tata Cara Pemberian dan Pembatalan Hak Atas Tanah Negara dan Hak Pengelolaan, sepanjang mengatur tata cara pembatalan Hak Atas Tanah Negara yang bertentangan dengan Peraturan ini dan defenisi pembatalan hak yang terdapat dalam Peraturan Menteri Negara Agraria/Kepala Badan Pertanahan Nasional Nomor 9 Tahun 1999; tidak bertentangan dengan substansi hukum yang ada dalam Peraturan Kepala Badan Pertanahan Nasional (Perkaban) No. 3 Tahun 2011.

Ketentuan dalam Peraturan Kepala Badan Pertanahan Nasional (Perkaban) No. 3 Tahun 2011 tidak secara khusus mengatur mengenai pembatalan hak atas tanah namun diatur dalam ketentuan mengenai penyelesaian kasus pertanahan pada Bab VII dengan memberikan pengaturan bahwa penyelesaian kasus pertanahan pada dasarnya ada 2 (dua) yaitu 1) pelaksanaan putusan pengadilan dan 2) penyelesaian kasus pertanahan di luar pengadilan. Pelaksanaan putusan pengadilan serta penyelesaian kasus pertanahan di luar pengadilan dapat melahirkan perbuatan hukum berupa pembatalan sertipikat hak atas tanah sehingga dapat dikatakan bahwa jika didasarkan pada Peraturan Kepala Badan Pertanahan Nasional (Perkaban) No. 3 Tahun 2011 maka pembatalan hak atas tanah dapat dilakukan dengan 2 (cara) yakni 1) berdasarkan putusan pengadilan dan 2) tidak berdasarkan putusan pengadilan. Pasal 55 Perkaban No. 3 Tahun 2011 menegaskan bahwa Tindakan untuk melaksanakan putusan pengadilan yang telah memperoleh kekuatan hukum tetap, dapat berupa pelaksanaan dari seluruh amar 
putusan, pelaksanaan sebagian amar putusan dan/atau hanya melaksanakan perintah yang secara tegas tertulis pada amar putusan. Selanjutnya dalam ayat (2) ditegaskan bahwa amar putusan pengadilan yang telah memperoleh kekuatan hukum tetap, yang berkaitan dengan penerbitan, peralihan dan/atau pembatalan hak atas tanah, antara lain perintah untuk membatalkan hak atas tanah, menyatakan batal/tidak sah/tidak mempunyai kekuatan hukum hak atas tanah, menyatakan tanda bukti hak tidak sah/tidak berkekuatan hukum, perintah dilakukannya pencatatan atau pencoretan dalam buku tanah, perintah penerbitan hak atas tanah dan amar yang bermakna menimbulkan akibat hukum terbitnya, beralihnya atau batalnya hak.

Selanjutnya, Paragraf 2 tentang Proses Perbuatan Hukum Administrasi Pertanahan Terhadap Keputusan/Surat Cacat Hukum Administrasi dalam Pasal 64 ayat (3) menyebutkan bahwa Surat permohonan/usulan sebagaimana dimaksud pada ayat (1) dilampiri data pendukung antara lain, sertipikat hak atas tanah yang kedapatan cacat hukum administrasi, hasil pengolahan data yang membuktikan adanya cacat hukum administrasi, salinan amar putusan pengadilan atau pertimbangan hakim dalam menjatuhkan putusan yang substansinya menyatakan tidak sah dan/ atau palsu dokumen yang digunakan dalam proses penerbitan sertipikat hak atas tanah, surat-surat lain yang mendukung alasan permohonan pembatalan.

Menghubungkan antara kedua pasal di atas penulis menyimpulkan bahwa Perkaban No. 3 Tahun 2011 pada dasarnya memberikan pengaturan bahwa Pembatalan Sertipikat Hak atas Tanah yang didasarkan pada Putusan Pengadilan yang tidak secara tegas menyatakan batal sertipikat tetapi memiliki amar yang bermakna menimbulkan akibat hukum terbitnya, beralihnya atau batalnya hak dikategorikan sebagai pembatalan sertipikat hak atas tanah karena cacat admnistrasi sebagaiman dapat dilihat pada Pasal 6 ayat (3) huruf c yang memberikan pengaturan bahwa salah satu syarat dalam pengajuan pembatalan sertipikat karena cacat admnistrasi adalah salinan amar putusan pengadilan atau pertimbangan hakim dalam menjatuhkan putusan yang substansinya menyatakan tidak sah dan/ atau palsu dokumen yang digunakan dalam proses penerbitan sertipikat hak atas tanah; Ketentuan dalam Pasal 64 ayat (3) Perkaban No. 3 Tahun 2011 berarti pula bahwa pembatalan hak berdasarkan putusan pengadilan umum baik perdata maupun pidana dikategorikan sebagai pembatalan hak karena cacat administrasi dan hanya Putusan Peradilan Tata Usaha Negara yang dikategorikan sebagai cacat hukum karena hanya Putusan PTUN yang secara tegas memerintahkan pembatalan sertipikat hak atas sehingga pengkategorian lain mengenai pembatalan hak dalam perkaban No. 3 tahun 2011 menurut penulis dalah 1) pelaksanaan putusan pengadilan yang menyatakan batal sertipikat dan 2) pembatalan karena cacat admnistrasi yang terbagi menjadi 2 (dua) jenis yakni berdasarkan putusan pengadilan dan berdasarkan penelitian oleh Badan Pertanahan Nasional dan pembatalan hak tanpa melalui Putusan Pengadilan.

Pengkategorian Pembatalan sertipikat hak atas tanah yang dilaksanakan berdasarkan putusan peradilan umum baik perdata maupun pidana sebagai cacat admistrasi dalam Perkaban No. 3 Tahun 2011 menurut penulis merupakan pengkategorian yang tidak tepat karena Putusan Perdata ataupun pidana pada dasarnya tidak menyangkut administrasi dalam penerbitan hak tetapi menyangkut keabsahan pemilikan seseorang terhadap sebidang tanah yang dibuktikan dengan sertipikat. Sertipikat yang dibatalkan 
berdasarkan Putusan Perdata dilaksanakan bukan karena adanya kekeliruan dalam prosedur atau administrasi pada Kantor Pertanahan tetapi didasarkan pada Putusan yang menyatakan berhak atau tidaknya seseorang atas sebidang tanah di mana ketika proses penerbitan hak dilaksanakan, berhak tidaknya orang tersebut belum diketahui dan hal ini berarti Kantor Pertanahan tidak melakukan tindakan penerbitan yang mengandung cacat admnistrasi sehingga pembatalan sertipikat yang dilaksanakan jelas bukan karena cacat admnistrasi tetapi karena cacat hukum. Cacat hukumnya sertipikat tersebut didasarkan pada suatu Putusan Pengadilan yang in kracht. Kesimpulan penulis dalam hal ini adalah seluruh pembatalan sertipikat hak atas tanah yang dilaksanakan berdasarkan putusan pengadilan baik Tata Usaha Negara, Perdata maupun Pidana adalah pembatalan sertipikat karena cacat hukum bukan karena cacat admnistrasi.

Pembatalan sertipikat hak atas tanah karena cacat admnistrasi hanya dilaksanakan terhadap sertipikat yang diketahui secara di kemudian hari mengandung cacat dalam penerbitannya dan pembatalannya tidak membutuhkan putusan pengadilan tetapi dapat dilaksanakan oleh Badan Pertanahan Nasional setelah melalui mekanismemekanisme tertentu sehingga dapat diyakini bahwa secara nyata terdapat kekeliruan dalam admnistrasi ataupun prosedur penerbitan sertipikat hak tersebut. Penulis dalam hal ini lebih menyetujui pembagian pembatalan hak dalam KBPN No. 9 tahun 1999 yakni karena cacat hukum dan karena cacat admnistrasi. Pembatalan hak karena cacat admnistrasi dalam KBPN No. 9 Tahun 1999 merupakan pembatalan hak tanpa melalui proses peradilan tetapi karena ditemukan kekeliruan dalam penerbitan.

Pasal 6 ayat (2) Perkaban No. 3 Tahun 2011 menegaskan bahwa Cacat hukum administrasi sebagaimana dimaksud pada ayat (1) antara lain, kesalahan prosedur dalam proses penetapan dan/atau pendaftaran hak tanah, kesalahan prosedur dalam proses pendaftaran peralihan hak dan/atau sertipikat pengganti, kesalahan prosedur dalam proses pendaftaran penegasan dan/atau pengakuan hak atas tanah bekas milik adat, kesalahan prosedur dalam proses pengukuran, pemetaan dan/atau perhitungan luas, tumpang tindih hak atau sertipikat hak atas tanah, kesalahan subyek dan/atau obyek hak dan kesalahan lain dalam penerapan peraturan perundangundangan. Pasal 64 Perkaban No. 3 Tahun 2011 mengatur pula bahwa permohonan/usulan perbuatan hukum administrasi pertanahan terhadap sertipikat hak atas tanah yang cacat hukum administrasi dapat diajukan oleh pihak yang berkepentingan/pemohon atau kuasanya. Pasal 65 mengatur bahwa pihak yang berkepentingan sebagaimana dimaksud dalam Pasal 64 ayat (1) aparatur BPN RI yang mengetahui data dan/atau warkah penerbitan hak atas tanah yang tidak sah mengenai substansi dan/atau proses penerbitannya, aparatur BPN RI mempunyai bukti adanya kesalahan prosedur administrasi penerbitan sertipikat hak atas tanah dan pihak yang dirugikan akibat terbitnya sertipikat hak atas tanah yang cacat.

Dengan demikian secara yuridis normatif menunjukkan bahwa keputusan pembatalan suatu sertifikat oleh PTUN tidak secara otomatis akan merubah legalitas kepemilikan hak atas tanah seseorang, melainkan atas dasar keputusan PTUN tersebut dapat dijadikan alat bukti untuk menggugat legalitas kepemilikan hak atas tanah seseorang ke Pengadilan Negeri.

\section{PENUTUP}

Berdasarkan pembahasan di atas, penulis mengambil kesimpulan sebagai berikut :

1. Berdasarkan Ketentuan dalam Pasal 64 ayat (3) Perkaban No. 3 Tahun 2011 
dapat disimpulkan bahwa pembatalan hak berdasarkan putusan pengadilan umum baik perdata maupun pidana dikategorikan sebagai pembatalan hak karena cacat administrasi dan hanya Putusan Peradilan Tata Usaha Negara yang dikategorikan sebagai cacat hukum karena hanya Putusan PTUN yang secara tegas memerintahkan pembatalan sertipikat hak atas sehingga pengkategorian lain mengenai pembatalan hak dalam perkaban No. 3 tahun 2011 menurut penulis dalah 1) pelaksanaan putusan pengadilan yang menyatakan batal sertipikat dan 2) pembatalan karena cacat admnistrasi yang terbagi menjadi 2 (dua) jenis yakni berdasarkan putusan pengadilan dan berdasarkan penelitian oleh Badan Pertanahan Nasional dan pembatalan hak tanpa melalui Putusan Pengadilan.

2. Berdasarkan asas praduga sah (praesumtio iustae causa/vermoeden van rechtmatigheid) Keputusan Tata Usaha Negara selalu dianggap sah dan harus dilaksanakan sepanjang belum dibatalkan berdasarkan putusan pengadilan yang telah memperoleh kekuatan hukum tetap, dengan demikian adanya Keputusan PTUN tidak secara otomatis merubah legalitas kepemilikan Hak atas tanah seseorang, melainkan dengan keputusan PTUN tersebut oleh para pihak dapat dijadikan alat bukti ketika mengajukan gugatan kepemilikan hak atas tanah ke Pengadilan Negeri. Sedangkan terhadap Putusan Pengadilan Negeri yang terkait dengan adanya cacad yuridis dalam proses penerbitan sertifikat dapat menjadi dasar bagi pemilik hak atas tanah untuk menindaklanjuti ke BPN untuk proses penerbitan sertifikat berdasarkan Putusan Pengadilan yang telah berkekuatan hukum tetap.

\section{DAFTAR PUSTAKA}

Amiruddin \& Zainal Asikin, Pengantar Metode Penelitian Hukum, PT. Raja Grafindo Persada, Jakarta, 2004.

Anonim, Usulan Revisi Undang-Undang Pokok Agraria, Menuju Penegakan Hak-Hak Rakyat Atas Sumber-Sumber Agraria, Konsorsium Reformasi Hukum Nasional, Konsorsium Pembaharuan Agraria Rineka Cipta. 1998.

Apeldorn, L.J. van, Pengantar Ilmu Hukum, Jakarta, Pradnya Paramita, 1981.

Arikunto, Suharsini, Prosedur Penelitian suatu pendekatan praktek, Jakarta, 1997.

Boedi Harsono,Hukum Agraria Indonesia, Sejarah Pembentukan UUPA, Isi dan Pelaksanaannya, (Jakarta, Djambatan,2005

Bachriadi, Dianto, Erpan Faryadi, dan Bonnie Setiawan (Editor), Reformasi Agraria, Fakultas Ekonomi UI, 1997.

Bakri, Muhammad, Hak Menguasai Tanah Oleh Negara (Paradigma Baru 
Untuk Reformasi Hukum Agraria, Yogyakarta, Citra Media, 2007.

Dimyati, Khudzaifah, Teorisasi Hukum, Studi Tentang Perkembangan Pemikiran Hukum Di Indonesia 1945-1990, Muhammadiyah Universiry Press, 2004.

Effendie, bachtiar, Kumpulan Tulisan Tentang Hukum Tanah, alumni, Bandung, 1982.

Fajar, Mukti ND \& Yulianto Ahmad, Dualisme Penelitian Hukum, Normatif \& Empiris, Yogyakarta, Pustaka Pelajar, 2010.

Fuady, Munir, Hukum Bisnis dalam Teori dan Praktek, Buku kedua, Citra Aditya Bakti, Bandung, 1994.

Harsono, Boedi, Hukum Agraria Indonesia, Sejarah Pembentukan UndangUndang Pokok Agraria Isi dan Pelaksanaannya, Jilid I Hukum Tanah Nasional, Djambatan, Jakarta, 2002.

, Hukum Agraria indonesia, Himpunan Peraturan Hukum Tanah, Djambatan Jakarta, 1999

Hutagalung, Arie S., Tebaran Pemikiran Seputar Masalah Hukum Tanah, Yakarta, Lembaga Pemberdayaan Hukum Indonesia, 2005.

Ibrahim, Johnny, Teori \& Metode Penelitian Hukum Normatif, Bayumedia Publishing, 2005.

Janis Maladi, Antara Hukum Adat dan Penciptaan Hukum oleh Hakim, Yogyakarta, Mahkota Kata, 2009.

Juanda, 2004, Hukum Pemerintahan Daerah, Alumnni, Bandung,
Koesnadi Hardjasoemantri, Hukum Tata Lingkungan, Gadjah Mada Universitas Press, Edisi ketujuh, 2000

Mochtar Kusumaatmadja, Hukum, Masyarakat dan Pembinaan Hukum Nasional, Bandung, Bina Cipta, 1976.

Mochtar Kusumaatmadja, dan B. Arief Sidharta, Pengantar Ilmu Hukum, Suatu Pengenalan Pertama Ruang Lingkup Berlakunya Ilmu Hukum, Buku I, Bandung, Alumni, 2000.

Maria SW Sumardjono, , Kebijakan Pertanahan, Antara Regulasi dan Implementasi, Jakarta, Penerbit Buku Kompas, 2001.

Mertokusumo, R.M. Sudikno, Hukum dan Politik Agraria, Jakarta, Karunika, Universitas Terbuka, 1988.

Muchsin, dkk., Hukum Agraria Indonesia dalam Perspektif Sejarah, Bandung, Refika Aditama, 2007.

Prajudi Atmosudirjo,1994, Hukum Administrasi Negara, Cetakan Kesepuluh, Ghalia Indonesia, Jakarta

Parlindungan, A.P., Komentar Atas Undang-Undang Pokok Agraria, Bandung, Alumni, 1988.

Pusat Bahasa Departemen Pendidikan Nasional, Kamus Besar Bahasa Indonesia, Jakarta, Balai Pustaka, 2003.

SF. Marbun, 1997, Peradilan Administrasi Negara dan Upaya Administrasi di Indonesia, Liberty, Yogyakarta, 


\section{Peraturan Perundang-undangan :}

Undang Nomor 5 Tahun 1960 Tentang Pokok Agraria

Undang-undang Nomor 32 Tahun 2004

TentangPemerintahan Daerah

Undang-Undang Nomor 5 Tahun 1986 tentang Peradilan Tata Usaha Negara sebagaimana telah diubah beberapa kali dan terakhir dengan Undang-Undang Nomor 51 Tahun 2009 tentang Perubahan Kedua Atas Undang-Undang Nomor 5 Tahun 1986 tentang Peradilan Tata Usaha Negara.

Peraturan Pemerintah Nomor 24 Tahun 2007 tentag Pendaftaran Tanah 